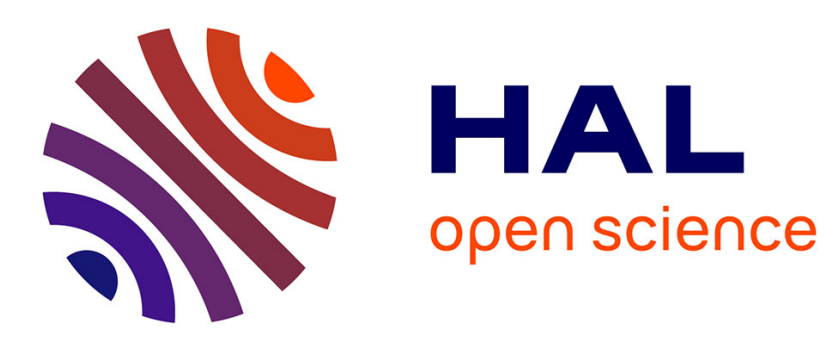

\title{
A broken plate beneath the North Baikal rift zone revealed by gravity modelling
}

E.B. Burov, Houdry F., M Diament, Jacques Déverchère

\section{To cite this version:}

E.B. Burov, Houdry F., M Diament, Jacques Déverchère. A broken plate beneath the North Baikal rift zone revealed by gravity modelling. Geophysical Research Letters, 1994, 21 (2), pp.129-132. 10.1029/93GL03078 . insu-01354155

\section{HAL Id: insu-01354155 \\ https://hal-insu.archives-ouvertes.fr/insu-01354155}

Submitted on 17 Aug 2016

HAL is a multi-disciplinary open access archive for the deposit and dissemination of scientific research documents, whether they are published or not. The documents may come from teaching and research institutions in France or abroad, or from public or private research centers.
L'archive ouverte pluridisciplinaire HAL, est destinée au dépôt et à la diffusion de documents scientifiques de niveau recherche, publiés ou non, émanant des établissements d'enseignement et de recherche français ou étrangers, des laboratoires publics ou privés. 


\title{
A broken plate beneath the North Baikal rift zone revealed by gravity modelling
}

\author{
E. B. Burov ${ }^{1 *}$, F. Houdry ${ }^{2}$, M. Diament ${ }^{1}$, J. Déverchère ${ }^{2}$
}

Abstract. We modelled a $1200 \mathrm{~km}$ long gravimetric profile in the North Baikal rift to assess the mechanical behaviour of the lithosphere, using a numerical model that accounts for realistic brittle-elasto-ductile rheology. We use published seismicity and refraction data, a new $5^{\prime} \times 7.5^{\prime}$ free-air/Bouguer gravity and topography data set, and a detailed map of faults obtained from high resolution SPOT imagery. Analysis of the gravity field over the North Baikal rift zone indicates significant asymmetry of the mechanical processes governing the deformation of the diverging sides of the rift. These anomalies cannot be explained by a conventional continuous plate undergoing extension beneath the rift zone, whereas a strong mechanical discontinuity (wedge shaped detachment zone beneath the rift axis) is able to reproduce observations. Such a discontinuous model provides a good fit to the gravity and crustal thickness data and explains the deep seismicity reported there.

Introduction

Among the present-day continental rift systems, the Baikal rift zone (BRZ) is believed to represent an archetypal rift in the initial stages of continental plate divergence. This conventional rifting model manly implies thinning of the crust and negligible lithospheric strength, at least in the vicinity of the rift axis, on the basis of high heat flow and intense normal faulting throughout the upper crust. However, recent studies based on depth distribution of earthquakes, flank uplift patterns, and gravity anomalies over the East African rifts [Shudofsky et al., 1987; Ebinger et al., 1989], the Rio Grande rift [Olsen et al., 1987], or BRZ [Diament and Kogan, 1990; Déverchère et al., 1991; Ruppel et al., 1993] provide evidence for a high mechanical strength within the lithosphere subject to extension. Analytical and numerical models confirm that plate flexure must be considered in this context to explain uplifted rift flanks that rise over $1 \mathrm{~km}$ above the surrounding topography [e.g., Weissel and Karner, 1989; Chéry et al., 1992]. In the eastern BRZ, hypocenter relocations show widespread and unusual seismic deformation throughout the upper $30 \mathrm{~km}$ of the crust [Déverchère et al., 1993], in a region where interpretation of seismic refraction and reflection data indicate a thicker crust $(40-44 \mathrm{~km})$ than in the southern rift $(35-39 \mathrm{~km})$ or in the surrounding stable zones (around $40 \mathrm{~km}$ ) [Puzyrev et al., 1978; Zorin et al., 1989; Logatchev and Zorin, 1992]. In addition to the absence of crustal thinning, it was also suggested [e.g., Ruppel, 1992], that significant effective elastic thickness $(T e)$ of the lithosphere $(\sim 50 \mathrm{~km}$, [Ruppel et al, 1993]), low heat flow, deep seismicity (hypocenters as deep as 60 km, [Déverchère et al., 1991; 1993]), and, finally, an absence of volcanic activity (Figure 1) suggest that the North Baikal rift (NBR) is rather atypical. In this paper, we analyse the short wavelength gravity field in order to investigate the crustal thickness variations and mechanical lithospheric properties beneath the NBR. This is done through the study of density contrasts associated with the Moho and modelling of the mechanical behaviour of the

\footnotetext{
1 Gravimétrie et Géodynamique, Institut de Physique du Globe de Paris

*n leave from Institute of Physics of the Earth

also at Department of Earth Sciences/GETECH, University of Leeds

2 Laboratoire de Géodynamique Sous-Marine, Universite Paris VI
}

Copyright 1994 by the American Geophysical Union. lithosphere along representative profiles (Figures 1,2). We focus on the north-eastern rift, where the surface expression of extension is clear, earthquake distribution related to major faults is constrained with high accuracy ( $\pm 2 \mathrm{~km}$, [Déverchère et al., 1993]), surface geology is known [Houdry et al., 1993], as are the depth and geometry of the sedimentary basins [Logatchev and Zorin, 1992]. The sedimentary basins are clearly distributed in an enéchelon pattern over a broad area (about $300 \mathrm{~km}$ ) where the Proterozoic and Paleozoic granitoids are more homogeneous, than across the Central and Southern BRZ located on the suture zone between the Siberian platform and the folded mountain ranges of Caledonian Sayan-Baikal belt (Figure 1). This area is presently dominated by $\mathrm{N} 160^{\circ}$ extension [Doser, 1991; Déverchère et al., 1993] that could have been preceded by an about $\mathrm{N} 115^{\circ}$ extension [Houdry et al., 1993]. The latter would have favoured a strike-slip component along the major border faults.

\section{Gravity field analysis and Mechanical Modelling}

We used the topography and gravity data set provided by the International Scientific Environmental Centre of Russian Academy of Sciences (ISEC). It consists of $5^{\prime} \times 7.5^{\prime}$ free air (FAA) and complete Bouguer gravity anomaly (BA) grids, including terrain corrections (within $200 \mathrm{~km}$ of gravity stations), and corresponding elevations (Figure 2). The resolution of the original point data is reported to be around 1 ' $\times l^{\prime}$, the accuracy of FAA is about 2-4 mgal [M. Kogan, pers. comm.]. The digital topography was checked with the ONC topography (Operational Navigational Charts, Defence Mapping Agency) and showed a good agreement in the study area (Figure 3). To separate the lithospheric and deep sub-lithospheric sources of the observed gravity anomaly, we computed a sum of 10 first harmonics of the gravity field (GRIM-3L1 global field model [Reigber et al., 1985]). This long wavelength component appears to provide only a slight negligible EW trend of $0.5-1$ mgal per $100 \mathrm{~km}$ (Figure 3). To constrain the sediment thickness in the basins, the faults geometry and the crustal thickness, we used topographic cross-sections combined with geophysical data from Puzyrev et al. [1978], Zorin et al. [1989], Krylov et al. [1990], Logatchev and Zorin [1992] and Déverchère et al. [1993]. The original complete BA, provided by ISEC, adopts crustal density of $2300 \mathrm{~kg} / \mathrm{m}^{3}$. Using the original FAA, we extracted the terrain corrections from the old complete BA and recomputed BA for more realistic value of $2670 \mathrm{~kg} / \mathrm{m}^{3}$ (Figure 2). To account for surficial density variations, we also corrected BA over the sedimentary basins for the effect of sedimentary fill, assuming density of sediments $\rho=2400 \mathrm{~kg} / \mathrm{m}^{3}$ This correction does not exceed $10-15 \mathrm{mGal}$. We did not account for the dense batholith inclusions reported on the north side of the rift [Yu. Zorin, pers. comm.], due to the absence of data on their exact location, depth and geometry.

The linear shape of the gravity anomaly in the northeast direction (direction of the rift axis, Figures 1, 2) advocates for 2D analysis. We compiled data along seven $1200 \mathrm{~km}$ profiles in the direction of the present day extension (roughly perpendicular to the major structures of the axial Upper Angara Basin, Figures 1, 2). A $800 \mathrm{~km}$ segment of the most representative profile $A^{\prime}-A$ is shown in Figure 3. Analysis of the Bouguer gravity profiles reveals significant deviations from the local (Airy) isostatic equilibrium model (Figure 3). The major signature of the deviations is the positive anomaly of about $40-50 \mathrm{mGal}$ observed $100-150 \mathrm{~km}$ to the northwest of the rift axis (Upper Angara basin) and the asymmetric negative anomaly observed $100-150 \mathrm{~km}$ to the south of the rift axis (Tsipa-Baunt Basin). The topography far to the north of the Upper Angara Basin is too low and flat to trace out any significant difference between local and regional compensation. 


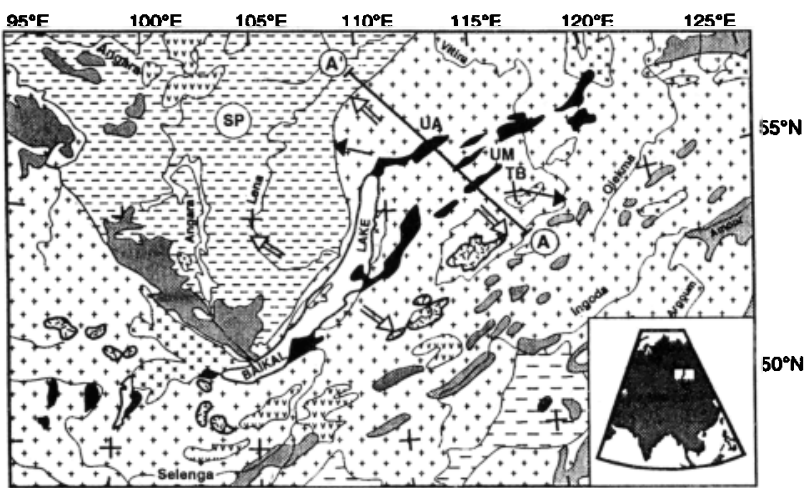

Cenozoic sedinents (Balkal rift conc) Mesozoic (Trussic) wolcanic rucks

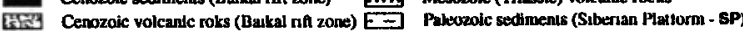

cen

UA - Upper Angara Basin

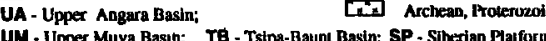

Fig. 1. Geological context of the Baikal rift zone (simplified from the Geological World Atlas, UNESCO, 1976). The line (A-A') is a $800 \mathrm{~km}$ part of the representative gravimetric profile used for this study (Figures 2, 3 and 4). White arrows are the directions of extension obtained from stress tensor analysis (for the northern part of the rift, Déverchère et al. [1991; 1993]; for the middle part of the rift, Doser [1991]). Thin black arrows are the direction of fault movement from geological observations, including field scarp measurements and SPOT imagery analysis [Houdry et al., 1993].

To explain BA over the rift, we first tried several traditional continuous plate models of regional (flexural) compensation of the topography. We began from the simple flexural models based on elastic plate approximation and end with more realistic plasto-

\section{Baikal. Free-Air gravity anomaly}

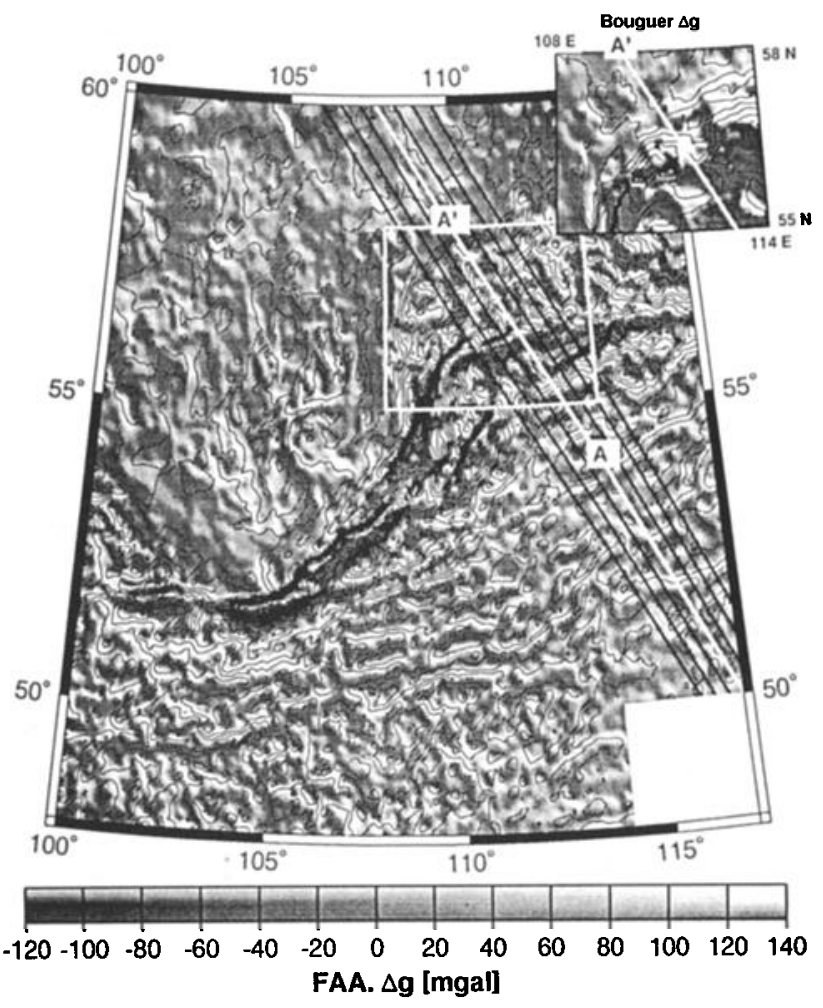

Fig. 2. The BRZ: 5' $\times 7.5^{\prime}$ Free Air (FAA) and complete Bouguer gravity anomaly data with location of 7 data profiles running across the NBR. The contour interval is $20 \mathrm{mgal}$. The grey shade interval is $10 \mathrm{mgal}$. The shade scale for BA is to be shifted by -90 mgal as compared to that for FAA. elasto-viscous (brittle-elasto-ductile) rheology models, implying experimental rock mechanics data [Burov and Diament, 1992]. The latter models use the Byerlee law of brittle failure for the uppermost crust and mantle, and power law creep within the ductile domains [Kirby, 1987] $\left(\dot{\varepsilon}=A^{*} \exp \left(-H^{*} / R T\right)\left(\sigma_{1}-\sigma_{3}\right)^{n}\right.$, where $\dot{\varepsilon}$ is the strain rate; $A^{*}$ is a material constant, $A^{*}=5.6 \times 10^{6}$ and $4.8 \times 10^{6}$ $\mathrm{MPa}^{-n} \mathrm{sec}^{-1}$ for quartz (upper crust) and olivine (mantle), respectively; $H^{*}$ is the activation enthalpy, $H^{*}=0.19 \times 10^{6} \mathrm{~J} \mathrm{~mol}^{-1}$ for quartz and $0.533 \times 10^{6} \mathrm{~J} \mathrm{~mol}^{-1}$ for olivine; $R=8.3144 \mathrm{~J}\left(\mathrm{~mol} \mathrm{~K}^{-1}\right.$ is the gas constant; $T[\mathrm{~K}]$ is the temperature; $n=3$ for quartz and 3.5 for olivine [Kirby, 1987]; $\sigma_{1}, \sigma_{3}$ are the principal stresses). The condition of the brittle failure is: $\sigma_{3}=\left(\sigma_{1}-\sigma_{3}\right) / 3.9$ if $\sigma_{3}<120 \mathrm{MPa}$ and $\sigma_{3}=\left(\sigma_{1}-\sigma_{3}\right) / 2.1-100$ if $\sigma_{3}>120 \mathrm{MPa}$ [Byerlee, 1978].

As compared to the other continental rift zones, the average $T_{e}$ for the BRZ is relatively high ( $\sim 50 \mathrm{~km}$, [Ruppel et al., 1993]), but it is much lower than the maximum mechanical thickness of 80-100 $\mathrm{km}$ that could be expected for a lithosphere of this age (400 to 700 Ma, [Logatchev and Zorin, 1992]). This upper strength limit implies a strong lower crust dominated by rocks with high temperature of creep activation $\left(\theta_{a}\right)$ (e.g. diabase, [Burov et al., 1993]). On the contrary, the observed low $T e(-50 \mathrm{~km})$ suggests that the lithospheric strength is reduced by decoupling of the strong upper
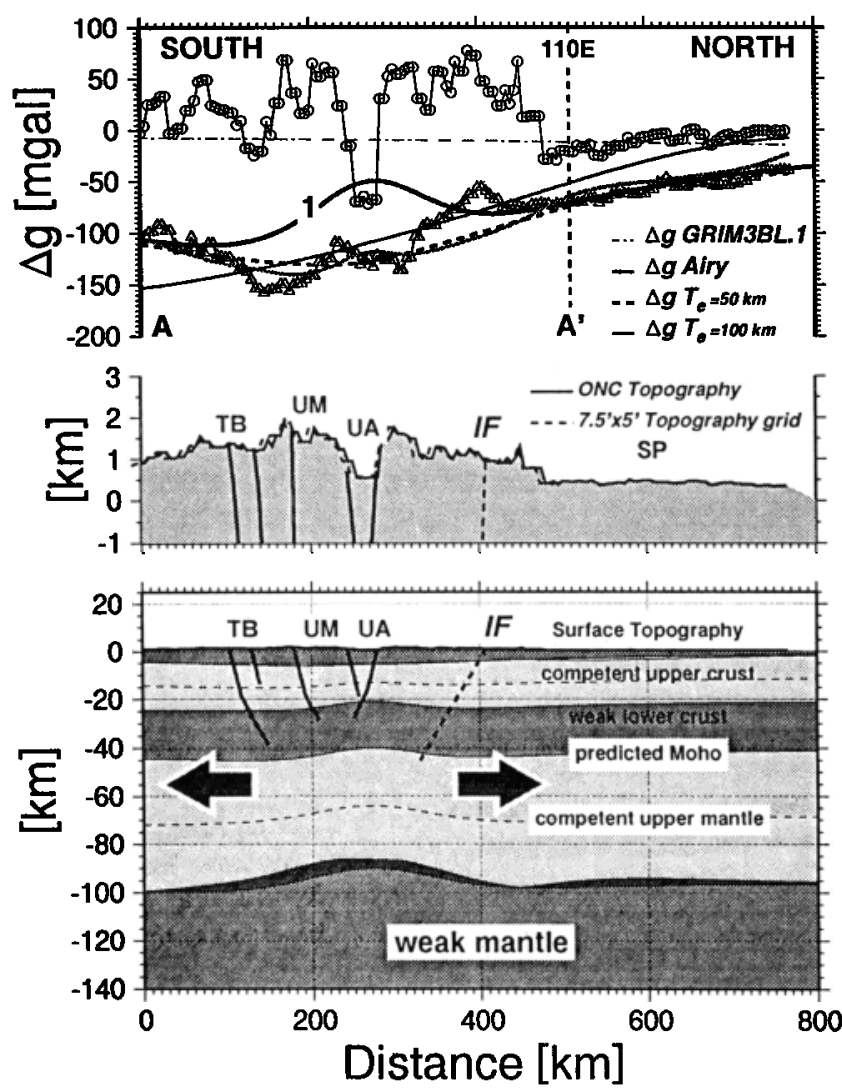

Fig. 3. The profile A-A'. Top: observed FAA, BA and theoretical $B A$ for continuous brittle-elasto-ductile plate models. Observed gravity anomalies: circles are the FAA; triangles are the BA; dashed line is the first 10 harmonics of the gravity field. Curve " $T e=50 \mathrm{~km}$ " is the theoretical BA for a plate with a weak decoupled lower crust and no horizontal extension (summary strength, in terms of $T e$, is $\sim 50 \mathrm{~km}$ ). Curve " $T e=100 \mathrm{~km}$ " is for the same model, but with a strong coupled lower crust. Curve 1 is a theoretical BA for a plate subjected to extension and flexure. Middle: topography and the interpretative fault geometries. Bottom: rheological structure of the extended plate. White areas are competent quasi-elastic zones. Grey areas are domains subjected to non-elastic deformation (brittle or ductile failure). Black areas are zones of additional nonelastic failure due to flexure. The uppermost mantle remains quasielastic and is free of plastic deformation, the crust and the lower mantle lithosphere undergo significant non-elastic strain. 
crust from the uppermost mantle by a weak (low $\theta a$ ) lower crust [Burov et al., 1993]. Therefore we chose low $\theta_{a}$ rheology (e.g. quartz) for the whole crust. This choice is partly validated by the presence of an intracrustal low velocity zone in the BRZ [Puzyrev, 1981], which might be associated with the weak lower crust.

A 2-D finite difference model accounting for the plasto-elastoviscous behaviour of the continental lithosphere was used to study geologically realistic scenarios of plate deformation. The evolution of the system is governed by mass, momentum and energy conservation equations [e.g., Bassi, 1991; Chéry et al.; 1992]:

$\left\{\rho \operatorname{det} G=\rho_{0} ; \operatorname{div} \sigma+\rho g=0 ; \rho C_{p} \dot{T}+\operatorname{div}(k \nabla T)=H_{r}+H_{d}\right\}$

where $\rho_{0}, \rho$ are the initial and current densities, $G$ is the gradient of deformation, $g$ is the gravity acceleration, $\sigma$ is the stress tensor, $C_{p}$ is the specific heat $\left(\rho C_{p}=3 \times 10^{6}, 4 \times 10^{6} \mathrm{~J}\left(\mathrm{~m}^{3} \mathrm{~K}\right)^{-1}\right.$ for the crust and the mantle, respectively), $k$ is the thermal conductivity tensor $\left(k_{I J}=2.5,2,3.5 \mathrm{~W}(\mathrm{mK})^{-1}\right.$ for the upper crust, lower crust and the mantle respectively), $H_{r}$ and $H_{d}$ are the radiogenic and dissipative heat production per unit volume [Burov et al., 1993]. To achieve rapid convergence of the non-linear finite difference algorithm, we use a semi-analytical non-elastic plate approximation [Burov and Diament, 1992] for the predictor/corrector scheme controlling the effective bending moment $M_{x}$, the longitudinal $\left(T_{x}\right)$ and the vertical shearing $\left(Q_{x}\right)$ force components per unit width of the plate:

$$
M_{x}=-\int_{0}^{\infty} \sigma_{x x}\left(y-y_{l}\right) d y ; T_{x}=-\int_{0}^{\infty} \sigma_{x x} d y ; Q_{x}=-\int_{0}^{\infty} \sigma_{x y} d y
$$

$y_{i}$ is the depth to the $i$ th neutral plane). The starting temperature distribution and yield-stress profiles were obtained from the solution of the heat transfer problem for the continental lithosphere [Burov et al., 1993], assuming thermal age of $400 \mathrm{Ma}$ and $\dot{\varepsilon} \sim 1 \div 3$ $\times 10^{-15} \mathrm{sec}^{-1}$ [Ruppel, 1992; Houdry et al., 1993]. Initialisation of necking requires an initial localised strength defect. Such defect was inferred beneath the axial Upper Angara basin (major depressed zone). We use information on the geometry and location of normal faults, deduced from high resolution SPOT imagery, field measurements [Houdry et al., 1993] and seismicity data [Déverchère et al., 1993] to consider fault-induced stresses.

\section{Results and Discussion}

The general result of these analyses is to show that continuous plate models of lithospheric extension fail to reproduce the observed gravity anomalies (Figure 3). Models of lithospheric flexure without extension produce BA that do not differ enough from the Airy anomaly (Figure 3). Models of extension with flexure [e.g., Cherry et al., 1992], that results in a crustal/mantle necking beneath the rift axis and consequent flexural uplift of the rift shoulders, yield a quasi-symmetric BA over the NBR (curve 1 in Figure 3), whereas the observed BA is anti-symmetric. Moreover, extension of a $400 \mathrm{Ma}$ continuous plate gives a relatively broad $(80-100 \mathrm{~km}$ in width) elevation of the Moho. This is larger than the width of the extensional province $(<45 \mathrm{~km})$, whereas the data suggest that the crust is not elevated beneath the NBR [Puzyrev et al., 1978; Zorin et al., 1989; Logatchev and Zorin, 1992], except a possible narrow uplift beneath the Angara Basin [Krylov et al., 1990].

Geological and morphological observations [Houdry et al, 1993] reveal a significant amount of past ESE/WNW strike-slip movement oblique to the direction of the present-day extension, obtained from stress tensor analysis [Déverchère et al., 1991] (Figure 1). The free strike-slip movements along the major border faults imply a mechanical discontinuity that could have allowed the relative displacements of the rift sides, oblique to the direction of the extension. The existence of such free displacements means that at least the crustal domains of the diverging rift sides should be mechanically cut (or "torn off") from each other. We tested this point by introducing a detached zone beneath the rift axis. This zone (wedge-shaped prism or block) is bounded from both sides by nearvertical zero strength free-slip bands (border faults, Figure 4). The
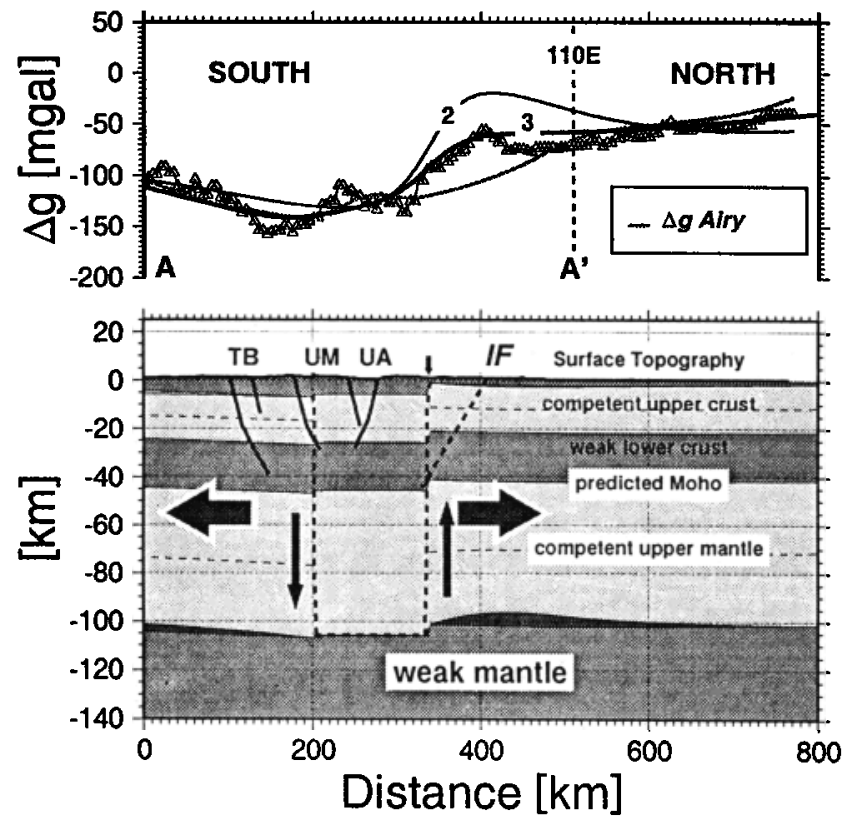

Fig. 4. Discontinuous model. A detachment zone, bounded by two discontinuities (dashes), is imposed beneath the rift axis. Curves 2 and 3 show the theoretical BA for different boundary forces set on the edges of the two plates: 1 - south $F=1 \times 10^{12} \mathrm{~N} / \mathrm{m}$, north $F=$ $2 \times 10^{12} \mathrm{~N} / \mathrm{m}$; 2 - south $F=1 \times 10^{12} \mathrm{~N} / \mathrm{m}$, north $F=-4 \times 10^{12} \mathrm{~N} / \mathrm{m}$. "IF" is the inferred Precambrian fault on the north side of the rift. The detached area resulted in unloading of the rift shoulders and stress redistributions that have lead to the asymmetric flexure. The bottom of the mantle lithosphere and the upper crust are submitted to non-elastic deviatoric strain. See Figure 2 for general notations.

southern boundary can be associated with the actually observed deep normal faults, the northern boundary could be related to a preexisting Precambrian fault, similar to those along the boundary between the Siberian platform and the Sayan-Baikal orogenic belt [V. Sankov, pers. comm.]. The rift sides interact with each other through vertical and horizontal boundary stresses acting on the intermediate detachment block (black arrows in Figure 4). In our numerical experiments, we varied the width (from 0 to $250 \mathrm{~km}$ ), position ( $\pm 100 \mathrm{~km}$ from the rift axis), geometry (wedge angles) and boundary conditions at the sides of this detachment block (boundary forces in a range of $10^{11}-10^{13} \mathrm{~N}$ per unit length). We found that to fit the observed gravity and Moho geometry, the detachment block should be approximately $150 \mathrm{~km}$ wide, with near vertical wedges (angle $80-60^{\circ}$ ). Varying the position of the south and north boundaries of the detached area, we found "the best fitting" location and amplitude of two steps in the Moho surface, associated with these boundaries (Figure 4, curve 3). The northern, most important step in the depth of the Moho, corresponding to a depth change from $47 \pm 2 \mathrm{~km}$ to $42 \pm 1 \mathrm{~km}$, coincides with the inferred Precambrian fault (IF, in Figure 4), thus justifying our initial assumption on its role. This result is confirmed by teleseismic data [Krylov et al., 1990], that point to a possibility of a localised uplift of the Moho from about $50 \mathrm{~km}$ to $42 \mathrm{~km}$ beneath the Angara basin, and with the field observation of $\sim 1 \mathrm{~km}$ surface uplift that could happen along this fault [V. Sankov, pers. comm.]. Our model predicts a comparable basement uplift on the north side of the rift although we cannot claim that it coincides exactly with this fault.

The resulting Moho geometry is asymmetric, with a positive step at the north and a negative step at the south. This yields an asymmetric gravity anomaly that fits the observations. The upward bending of the north rift side leads to an increase in the compressional deviatoric stress in the uppermost crust and mantle. This increases the brittle strength limits at the northern side, raises the Moho and crystalline basement in the vicinity of the rift, and then lowers them to the end of the profile. Conversely, the downward flexure of the southern side results in an increase in the extensional 
deviatoric stresses in the uppermost crust and mantle, and therefore decreases the limits of the brittle failure. This could explain the asymmetry in the seismicity and fault distributions on opposite sides of the NBR (Figure 3 and 4). The geometry of the detached area roughly coincides with the geometry of a system of normal faults that bound the basin and penetrate the lower crust at depths up to $30 \mathrm{~km}$ [Déverchère et al., 1993]. This area could be caused by tearing off of the rift neck during extension, e.g. by the past ESE/WNW strike-slip movement, oblique to the direction of divergence (the strike-slip component is now minor, probably after reorientation of the major stress axes from $\mathrm{N} 115^{\circ}$ to $\mathrm{N} 160^{\circ}$ [Déverchère et al., 1993]). This could result in the drop of the deviatoric stresses at the edges of the diverging rift sides and consequently in the elastic unloading of its shoulders, which has led to the practical restoration of their initial strength: the effective $T e$ became quite high, of about $45-55 \mathrm{~km}$, compared to $20-30 \mathrm{~km}$ that could be expected in the neck of a classical rift. Due to the asymmetric load redistribution that followed the internuption in horizontal stress transition, one of the shoulders (south) went $1-2 \mathrm{~km}$ down and the other one (north) went $4-5 \mathrm{~km}$ up. The "tom-off" neck is not a single possible mechanism that could explain the detachment of the north and south rift sides. The other possibility could be a large scale extensional "cracking" of the lithosphere due to heterogeneous stress/strain field created by the complex northwards movement of the Indian continent [Tapponnier and Molnar, 1979].

Conclusions

The analysis of the short wavelength gravity field in the light of seismological and geological data suggests that the NBR presents a quite untypical "broken" or "cracked" rift. We believe that the present behaviour of the diverging plates in the NBR is not associated with conventional rifting by stretching of the continuous lithosphere, but requires a mechanical discontinuity (block-like detachment zone) beneath the rift axis. Due to this detachment zone (its existence is confirmed by the past strike-slip faulting, supposedly resulting from the Asia-India collision [Tapponnier and Molnar, 1979]), the mechanical interaction between the sides of the rift is minor in the direction of divergence, resulting in that the lithospheric deformation is well explained by the flexural uplift/descent of the both detached sides of the rift.

Acknowledgements. We thank ISEC for access to their gravity data set, M. G. Kogan and Yu. Zorin for helpful comments on the manuscript. We are especially indebted to $\mathrm{C}$. Ebinger for her generous help in correcting the manuscript and constructive comments. We thank C. Ruppel for useful comments and providing parts of her thesis. E. B. Burov benefited from a post-doctoral grant of the Ministère de la Recherche and from partial support of GETECH. This work was partly supported by INSU-DBT (92), and Tectoscope (92). Contribution \# 1280 (IPGP), \# 637 (GEMCO).

\section{References}

Bassi, G., Factors controlling the style of continental rifting: insights from numerical modelling, Earth Planet. Sci. Lett., 105 , 430-452, 1991

Byerlee, J.D., Friction of rocks, Pure Appl. Geophys., 116, 615 626,1978

Burov, E.B., and M. Diament, Flexure of the continental lithosphere with multilayered rheology, Geophys. J. Int., 109, 449-468, 1992.

Burov, E.B., Lobkovsky, L.I., Cloetingh, S., and A.M. Nikishin, Continental lithosphere folding in Central Asia (part 2), constraints from gravity and topography, Tectonophysics, 226, 73-87, 1993.

Chéry, J., Lucozeau, F., Daignieres, M., and J.P. Villotte, Large uplift of rift flanks: A genetic link with lithospheric rigidity? Earth Planet. Sci. Lett., 112, 195-211, 1992.
Déverchère, J., Houdry, F., Diament, M., Solonenko, N.V. and A.V. Solonenko, Evidence for a seismogenic upper mantle and lower crust in the Baikal rift, Geophys. Res. Letters, 18, 6, 1099-1102, 1991.

Déverchère, J., Houdry, F., Solonenko, N.V., Solonenko, A.V., and V.A. Sankov, Seismicity, active faults and stress field of the North Muya Region, Baikal Rift: New insights on the rheology of extended continental lithosphere, J. Geophys. Res., 1993.

Diament, M., and M.G. Kogan, Long wavelength gravity anomalies over the Baikal rift and geodynamic implications, Geophys. Res. Lett., 17, 11, 1977-1980, 1990.

Doser, D., Faulting within the eastern Baikal rift as characterised by earthquake studies, Tectonophysics, 196, 108-139, 1991

Ebinger, C.J., Bechtel, T.D., Forsyth, D.W. and C.O. Bowin Effective elastic plate thickness beneath the East African and Afar Plateaux and dynamic compensation of the uplifts, $J$. Geophys. Res., 94, 2883-2901, 1989.

Kirby, S.H., and A.K. Kronenberg, Rheology of the Lithosphere Selected Topics, Rev. Geophys., 25, 1219-1244, 1987.

Krylov, S.V., Mishenkin, B.P., and A.V. Bryskin, Deep structure of the Baikal rift zone from multiwave seismic investigations, in: Logatchev, N.A. and Yu.A. Zorin (Eds.), Geodynamics of intracontinental mountainous terrains (in Russian), Nauka, Novosibirsk, 162-169, 1990.

Houdry, F., Gaudemer, Y., Sankov, V., and J. Déverchère, Geometry and rate of faulting during the Holocene in the North Baikal Rift Zone, Abstr. suppl. $N^{\circ} 1$ to Terra Nova, 5, EUG VII Strasbourg, C09-30, 259, 1993

Logatchev, N.A., and Y.A. Zorin, Baikal rift zone: Structure and geodynamics, Tectonophysics, 208, 273-286, 1992.

Olsen, K.H., Baldridge, W.S., and J.F. Callender, Rio Grande Rift: An overview, Tectonophysics, 143, 119-139, 1987.

Puzyrev, N.N., Mandelbaum, M.M., Krylov, S.V., Mishenkin, B.P., Petrik, G.V., and G.V. Krupskaya, Deep structure of the Baikal and other rift zones from seismic data, Tectonophysics, 45, 15-22, 1978.

Puzyrev, N. (Ed.), Baikal interiors according to the seismic data (in Russian), Izd. Akad. N. Sib. Otd., Novosibirsk, 1981.

Reigber C., Balmino G., Miller H., Bosch W., and B. Moynot, GRIM gravity model improvement using LAGEOS (GRIM3L1), J. Geophys. Res., 90, 7285-7299, 1985.

Ruppel, C. D, Thermal structure, compensation mechanisms, and tectonics of actively deforming continents: Baikal rift zone and large scale overthrust and extensional terrains, $P h . D$. thesis, Mas. Inst. of Technology, 292 p., 1992.

Ruppel, C. D, Kogan, M. G., and M. K. McNutt, Implications of new gravity data for Baikal rift zone structure, Geophys. Res. Lett., 20, 1635-1638, 1993.

Shudofsky, G.N., Cloetingh, S., Stein, S., and R. Wortel, Unusually deep earthquakes in East Africa: Constraints on the thermo-mechanical structure of a continental rift system, Geophys. Res. Lett., 14, 7, 741-744, 1987.

Tapponnier, P., and P. Molnar, Active faulting and Cenozoic tectonics of the Tien Shan, Mongolia, and Baykal regions, J. Geophys. Res., 84, 3425-3459, 1979.

Weissel, J.K., and G.D. Kamer, Flexural uplift of rift flanks due to mechanical unloading of the lithosphere during extension, J. Geophys. Res., 94, 13919-13950, 1989.

Zorin, Yu.A., Kozhevnikov, V.M., Novoselova, M.R., and E.K. Turutanov, Thickness of the lithosphere beneath the Baikal rift zone and adjacent regions, Tectonophysics, 168, 327-337, 1989.

E. B. Burov and M. Diament, Lab. Gravimétrie et Géodynamique, IPGP, 4 Place Jussieu, 75252 Paris Cedex 05, France

F. Houdry and J. Déverchère, Lab. de Géodynamique SousMarine - BP 48, 06230 Villefranche-sur-mer, France.

(Received: August 10, 1993; revised: October 18, 1993; accepted October 28, 1993) 